\title{
Clinical practice and basic education How to make them converge?
}

\section{Clínica y educación básica ¿Cómo hacerlas converger?}

\author{
ORIARD VALLE, Michel†** \& LÓPEZ MORENO, Azucena \\ Universidad Tecnológica de México (UNITEC), Campus Querétaro, Av. 5 de Febrero 1412, San Pablo, 76130 Santiago de \\ Querétaro, Qro
}

ID $1^{\text {st }}$ Author: Michel, Oriard Valle / ORC ID: 0000-0002-1186-0941, Researcher ID Thomson: S-5919-2018, CVU CONACYT ID: 781986

ID $1^{\text {st }}$ Coauthor: Azucena, López Moreno / ORC ID: 0000-002-4963-8342, CVU CONACYT ID: 632960

Received July 02, 2019; Accepted December 29, 2019

\begin{abstract}
The psychologist's job within basic education schools is increasingly requested, however, it is important to think about what is expected of that role. Managers, administrators, teachers, students and parents have different imaginaries about what a psychologist is, and making them converge might seem like an impossible task. The clinical listening, the intervention and the clinical look can be generators of a large number of structural and subjective movements within basic education context; these allow the infant to resist the transition in that period of his formation. Therefore the objective of this article was to think about the clinical psychologist's practice in basic education, from a direct type experience.
\end{abstract}

Clinical Practice, Education, Psychology

\section{Resumen}

El trabajo del psicólogo dentro de las escuelas de educación básica es cada vez más solicitado, sin embargo, es importante pensar en qué es lo que se espera de ese papel. Directivos, administrativos, docentes, estudiantes y padres de familia tienen un imaginario distinto de lo que es un psicólogo, y hacerlos converger podría parecer una misión imposible. La escucha, la intervención y la mirada clínica dentro del contexto de educación básica pueden ser generadores de una gran cantidad de movimientos estructurales y subjetivos; que permitan al infante resistir el tránsito por ese momento de su formación. Entonces, el objetivo de este artículo fue reflexionar sobre la práctica del psicólogo clínico dentro de la educación básica, a partir de una experiencia directa de este tipo.

Práctica Clínica, Educación, Psicología

Citation: ORIARD VALLE, Michel \& LÓPEZ MORENO, Azucena. Clinical practice and basic education How to make them converge? Journal of Systems and Educational Management. 2019. 6-19: 11-15

\footnotetext{
* Correspondence to Author (email: orvami@outlook.com)

$\dagger$ Researcher contributing as first author.
} 


\section{Introduction}

It is important, first of all, to mention that the text was developed from a specific experience within a private primary school in the state of Querétaro, Mexico, during 2017. Listening to talk about clinical psychology and basic education together can cause some confusion. Well, first of all, when you hear the word "education," the first reference around psychology goes to the educational side, but not to the clinic. So, if we listen to clinical psychology and elementary school, the questions primarily arise: "What does a clinical psychologist do inside an elementary school?" And "What don't clinicians only attend in an office and with a couch?"

The central idea of the text revolves around the discussion about the possible convergence of the practice of clinical psychology within the spaces where basic education takes place. The classrooms, the halls, the courtyards, the auditoriums are spaces susceptible to intervention to generate subjective movements from a critical view, facilitated by the observation of one who is dedicated to clinical psychology (Peusner, 2006).

The article is divided into four sections where it delves into the specificities of both clinical and basic education - emphasizing the fact that private education is spoken of - and the perspectives that are opened to make them converge.

\section{From the clinic}

The active listening and the look that provide training from the psychoanalytic clinic, open diverse possibilities in any space. Psychoanalysis is a disciplinary field composed of different theoretical models; However, each of them proposes ways to deal with suffering. Therefore, its attention space is not only limited to that of the offices (Paris, 2019).

The interventions are thought from the realities that are created daily, from the speeches that are transmitted and the links that they generate. These discourses are structuring, and if we take into account that children of school age are being talked about, the importance of what is transmitted grows (Rodulfo, 2019).
As Wittgenstein (2012) affirmed, the limits of our language mean the limits of our world and for a child, in our western context, the world basically develops in two spaces: the house and the school (Ibáñez-Salgado et al., 2012).

\section{Of private basic education}

Currently it seems that the issue of basic education aims to be a space attached to the psychiatrist where the ultimate goal is to diagnose everyone (Caponi, 2018). We know that the topic of diagnoses is delicate. Even the writing of a diagnosis, be it medical or psychological, and how it is interpreted has an impact on the social interactions of those who live with the diagnosed person (Dickison, Haerling, \& Lasater, 2019). Another difficulty to consider is the possible absence of commitment and involvement of parents with the specialist.

It seems that all children should be passed under a medical and psychological scanner to justify the actions that some teachers get to take inside the classroom (Ribeiro, 2015). Generating other subjective manifestations in children, such as tiredness, boredom, distraction, crying in the classroom; in short, various situations that supposedly should not happen since they are working and paying attention after staying in school for eight hours, with only thirty minutes of recess (in the best case).

The strict process of the transmission of knowledge has been prioritized, even though it is known that the essential is not what is taught, but the way in which it is transmitted (MelengeEscudero, 2018). This way of transmitting should aim to favor that the subjectivity of each boy and girl flourishes from their own referents, instead of being molded under the needs of a system that omits them.

This is one reason, among others, that highlights the importance of knowing the expectations, by way of social representations, of those who participate in academic processes (Hays et al., 2019). In other words, from what is considered important to transmit from parents to children, from teachers to children, from children to children, between parents and between teachers, practices are generated that are considered everyday and that, without knowing it, could cause subjective discomfort. 


\section{Of convergence}

This is the nodal point of the experience. Who ends up taking care of the children who go to school to look for loved ones? Who is in charge of attending to medical necessity (when in reality it is psychological)? It is right there where the function and the figure of the clinical psychologist come in. Its preliminary work involves obtaining information from different sources, such as the three main actors directly involved in the academic process: girls and boys, family members and teachers.

Thus, by knowing the conditions of the particular context in which the aforementioned actors coincide, you can favor with your interventions the existence of different dynamics to face the prejudices and social representations that exist about what it means to attend to the subjective manifestations that generate discomfort, since either in oneself or in others. In this understanding, the transformation of the child's psychosocial context is possible while realizing his unique process of constitution (Srinath, Jacob, Sharma \& Gautam, 2019).

In the private primary school of the state of Querétaro a diagnosis was made on the way of work carried out by the psychologists who had intervened in the school and all the comments agreed that: psychological work had never been done with the children, at least with teachers or parents. Hence, a revaluation of the work of psychologists in this context is relevant for their social function to contribute to subjective changes (Parker, 2014; Dickison, Haerling \& Lasater, 2019).

The plan to replicate the Children, Girls and Young Peacebuilders program was developed and subsequently to carry out the activities requested by the head teachers of each group. Work teams were organized for emotional containment groups and an agenda for individual attention to children who were channeled to the psychology department. The channeling was carried out by teachers through an instrument designed to be able to detect what aspect (s) it was (n) that they detected as priorities to be taken care of and, as a result, be able to carry out the intervention that was considered as more prudent.

\section{Methodology developed}

The Children, Girls and Young Peacebuilders program was taken as a reference for the intervention. Program developed in Manizales, Colombia, by the Center for Advanced Studies in Children and Youth (CINDE). This consists of six modules and three training moments (Ospina-Ramírez \& Ospina-Alvarado, 2017). In the first moment a group is chosen that will be formed with the six modules and, in turn, will be the one that forms the one that will participate in the second moment.

The training modules are: context, affective potential, communicative potential, creative potential for conflict transformation, ethical potential and political potential. During this first moment of formation, participatory group techniques and group reflection spaces are carried out to develop each potential.

In the second moment is the multiplication, in which a second group is chosen that will be formed by the first in the same subjects. The last moment provides a recreational space for meeting with the community (in this case, student) to share what has been done by both groups and it is called "Days for Peace".

Even though this was the main reference, group activities were also carried out with children, with their teachers and with managers. These were based on the observations made by the teachers, with the intention of supporting their group and, sometimes, to carry out the events that are organized inside the school. Similarly, psychological attention was provided individually in specific cases, holding interviews with children and their parents. Finally, emotional containment groups were held with teachers.

\section{Results}

Active listening, giving ears to those who are never heard because they have been dissolved in erroneous and hurried diagnoses, provides a different place and recognition. Listening to those people who are always treated as machines and not as human beings with needs and desires, provides possibilities for discursive movements.

The interventions made with teachers allowed a different relationship between them and mainly towards the director of the school. 
The interventions carried out with children favored the generation of their own and collective strategies to solve conflicts between peers and to overcome problematic aspects at home (in most cases).

The interventions made with parents, allowed them to get closer to their children, since many times, they had to ask permission in their work to attend an appointment that had to do directly with their children or a work session to which they were summoned by the tutor teachers of each group.

These approaches between the three actors directly involved in the formative academic process (parents, children, teachers) favored that within the school they were questioned practices that were considered effective because they had been carried out from that time. way.

Initially, a group of students and their parents were summoned together with their teachers. The first moment of training was somewhat rough due to the times and prejudices, however, it was achieved.

For the second moment the conditions were not the best. Because from the first formative moment important aspects of disagreement moved, especially on the part of parents and teachers. The director of the school did not allow the project to continue as previously planned and this led to the implementation of group interventions.

\section{Acknowledgments}

We thank the Center for Advanced Studies in Children and Youth and the University of Technology of Mexico for their support to the development of this research work.

\section{Conclusions}

On education it is concluded that there is still a lot of work to be done in this field to favor the continuity of processes that allow the clinic to have the expected impact by those who exercise it. We know that it is not an easy task, however, it is necessary to listen and look at clinicians who promote subjective and structuring movements within the educational spaces.
A subjectivity that needs to be heard in spaces where children are indicated with some personal situation, such as communication difficulties at home, to interact with their peers, to be present and attentive in school, requires interventions that favor girls and children find a safe place to be and be in school.

It is evident that anything that generates movements in the status quo will be seen as a threat when the conditions of the psychosocial context reinforce power relations in favor of prejudices and social representations that restrict the recognition and involvement of the actors in the academic process. Therefore it is essential to problematize that place and think about how to improve, especially if it means changing your mind about something that was believed to be the best way to do things.

The best way to know if the effects of interventions from the eyes and clinical scores are important in school dynamics, would be to have continuity with the processes. What might seem in primary schools in the private sector as a task practically impossible to achieve.

Carrying out these types of strategies implies an ethical-political position to sustain, since it implies a position before the world and, in turn, an effort to make way for clinical psychology in various spaces.

\section{References}

Caponi, S. (2018). La psiquiatrización de la vida cotidiana: el DSM y sus dificultades. Metatheoria-Revista de Filosofía e Historia de la Ciencia, 8(2), 97-103.

Desselle, S. P., Shane, P., Berhane, H., Samuel, Y., \& Tran, T. (2019). The effectiveness of written communication for decision support in clinical practice. Research in Social and Administrative Pharmacy.

Dickison, P., Haerling, K. A., \& Lasater, K. (2019). Integrating the National Council of State Boards of Nursing Clinical Judgment Model Into Nursing Educational Frameworks. Journal of Nursing Education, 58(2), 72-78. 
Hays, E., Levine, J., Rethi, S., Smith, E. K., Upadhya, S., Sobering, A. K., \& Weiler, T. (2019). Reevaluating Biochemistry and Nutrition Education Through Opinions of Clinicians and Educators. Medical Science Educator, 29(1), 189-197.

Ibáñez-Salgado, N., Díaz-Arce, T., DrukerIbáñez, S., \& Rodríguez-Olea, M. S. (2012). La comprensión de la diversidad en interculturalidad y educación. Convergencia, 19(59), 215-240.

Melenge-Escudero, J. (2018) La educación en el siglo XXI. Nociones y experiencias de la pedagogía crítica y la educación popular. San Salvador: Instituto Nacional de Formación Docente.

Ospina-Ramírez, D. A., \& Ospina-Alvarado, M. C. (2017). Futuros posibles, el potencial creativo de niñas y niños para la construcción de paz. Revista Latinoamericana de Ciencias Sociales, Niñez y Juventud, 15(1), 175-192.

Paris, J. (2019). An Evidence-based Critique of Contemporary Psychoanalysis: Research, Theory, and Clinical Practice. Routledge.

Parker, I. (2014). Discourse dynamics (psychology revivals): Critical analysis for social and individual psychology. Routledge.

Peusner, P. (2006). Fundamentos de la Clínica Psicoanalítica Lacaniana con Niños: De la interpretación a la transferencia. Buenos Aires: Letra Viva.

Ribeiro, R. (2015). Patologización de la infancia cotidiana. Teoría y Crítica de la Psicología, (5), 148-156.

Rodulfo, R. (2019). En el juego de los niños: Un recorrido psicoanalítico desde las escondidas hasta el celular. Argentina: Paidós.

Srinath, S., Jacob, P., Sharma, E., \& Gautam, A. (2019). Clinical practice guidelines for assessment of children and adolescents. Indian journal of psychiatry, 61(Suppl 2), 158.

Wittgenstein, L. (2012) Tractatus LogicoPhilosophicus. México: Alianza Editorial. 